under the action of several histamine-releasing substances is in progress and will be published later.

IvaN Mota

ItTamar VugmaN*

Laboratory for Cell Physiology and

Department of Histology,

Faculty of Medicine,

University of São Paulo.

$$
\text { Sept. } 27 .
$$

* Fellow from the C.A.P.E.S.

${ }^{1}$ Riley, J. F., and West, G. B., J. Physiol., 117, $72 P$ (1952); 120 528 (1953). Riley, J. F., Science, 118, 3064 '(1953)

${ }^{2}$ Mota, I., Beraldo, W. T., Ferri, A. ;G., and Junqueira, L. C. U. Nature, 174, 698 (1954). West, G, B., J.Pharm. Pharmacol., 7, 80

${ }^{3}$ Wilander, O., Scand. Arch. f. Physiol., Supp. 15 (1939). Jaques, L. C., and Waters, E. T., J. Physiol., 99, 454 (1941). Mota, I. and Yoneda, S., paper presented to Soc. Brasileira Anat. (1952) Riley, J. F., Proc. Soc. Exp. Med., Dundee Meeting (1952) Riley, J. F., J. Path. Bact., 65, 471 (1953). Mota, I., thesis Univ. of Sa Paulo (1953). Mota, I., Beraldo, W. T., and Junqueira, L. C. U., Proc. Soc. Exp. Biol. Med., 83, 455 (1953).

"Snedecor, G. W., "Statistical Methods" (Ames, Iowa State College Press, 1946).

'Mota, I., Beraldo, W. T., Ferri, A. G., and Junqueira, L. C. U. Fistamine Symposium, Ciba Foundation (London, April 1955) (in the press).

- Feinberg, S. M., and Sternberger, L. A., J. Allergy, 26, 170 (1955).

'Feldberg, W., and Mongar, J. L., Brit. J. Pharmacol. Chemother. 9. 197 (1954).

\section{Labelled Pronuclei in Mouse Eggs fertilized by Labelled Sperm}

Approximately 38 days after injecting adenine-8. ${ }^{14} \mathrm{C}$ into mature male mice, ejaculated sperm showed an autoradiograph in smear preparations'. Pronuclei in eggs fertilized by labelled sperm have been examined for autoradiographs.

Fallopian tubes from a superovulated female, killed approximately $12 \mathrm{hr}$. after mating to one of these males, were fixed in Bouin. They were sectioned at $10 \mu$, bleached in lithium carbonate, and coated with Kodak stripping film. The sections were stained with celestine blue and studied under a phasecontrast microscope.

Of twelve eggs examined, eleven had two pronuclei, and one had three pronuclei. In each bipronucleate egg one pronucleus showed an autoradiograph, and was assumed to be male. The unlabelled pronucleus was nearer the second polar body in six out of seven eggs in which the distance could be estimated; this agrees with the morphological evidence of the proximity of the female pronucleus to the second polar body. A possible autoradiograph on the vitellus of some eggs was perhaps related with the path of entry of the sperm. Spermatozoa in the perivitelline space, in the lumen of the tubes, and in the cumulus showed distinct autoradiographs.

In the tripronucleate egg, two pronuclei showed autoradiographs. The egg was presumably dispermic. The labelled pronuclei were larger than the third, and the second polar body had been extruded; this evidence supports the postulate of dispermy ${ }^{2}$.

Calculation from data of total incorporation of the tracer in sperm ${ }^{1}$ shows that for a pronucleus with diameter $20 \mu$, sectioned at $10 \mu$, and assuming all the tracer from the sperm to be present in the pro. nucleus and evenly distributed, the maximum density of the autoradiograph could be approximately $0.2 \times 10^{7}$ grains $/ \mathrm{cm}^{2}{ }^{2}$. This value is at the limit for recognition ${ }^{3}$. But usually the tracer is concentrated in certain parts of the pronucleus, and this gives a more contrasted autoradiograph which can be clearly recognized.

We wish to acknowledge the receipt of grants from the University of Edinburgh and the Agricultural Research Council (R. G. E.), and from the British Council and the British Empire Cancer Campaign (J. L. S.).

R. G. EDWARDS

J. L. SrRLIN

Institute of Animal Genetics,

West Mains Road,

Edinburgh 9.

Sept. 24.

${ }^{1}$ Sirlin, J. L., and Edwards, R. G., Exp. Cell Res., [9, 596 (1955)].

${ }^{2}$ Austin, C. R., and Braden, A. W. H., Exp. Cell Res., 8, 163 (1955). "Pele, S. R., "Isotopes in Biochemistry", 126 (J. and A. Churchill,

\section{Conversion of Phenylalanine into Tyrosine in the Silkworm Larva (Bombyx mori)}

In silkworms, it has been found that tyrosine is used not only for biosynthesis of the silk proteins ${ }^{1}$, but also to form melanin pigments, but little is known of its origin. The present work was carried out, using phenylalanine labelled with carbon-14, to examine whether phenylalanine is a precursor of tyrosine.

Radioactive L-phenylalanine,

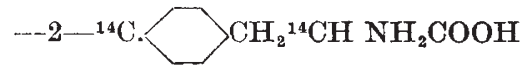

(0.84 me. per m.mol.), was obtained from the Radiochemical Centre. $\quad 0.5 \mu \mathrm{c}$. of radioactive phenyl. alanine $(99 \mu \mathrm{gm}$. as amino-acid) per worm was injected into the body cavity of the silkworms, Si $122 \times N i c h i 122 \pi$, at the fourth day of the fifth instar. Following the injection, these silkworms continued to feed normally for $72 \mathrm{hr}$. and then they began spinning their cocoons. Specific activity of the cocoon fibres measured with an $S C .16$ windowless gas-flow counter (Tracerlab Inc.) was $4 \cdot 154 \mathrm{c} / \mathrm{min} . /$ $100 \mathrm{mgm}$. (average). $4.86 \mathrm{gm}$. of the radioactive cocoon fibres was cut into small pieces and degummed by boiling with distilled water and $M / 50$ sodium carbonate solution repeatedly, until the weight of fibroin became constant. The fibroin was washed with ethanol and ether, and dried; the yield was $3.47 \mathrm{gm}$. $3.47 \mathrm{gm}$. of fibroin was hydrolysed with concentrated hydrochloric acid as usuel. Tyrosine was isolated directly from the hydrolysate according to the procedure of Abderhalden ${ }^{2}$. From the filtrate from which tyrosine had been removed, glycine was removed as a salt of 5-nitro-naphthalene-1-sulphonic acid, and then alanine as azobenzene $p$-sulphonate, and these amino-acids were separated from their respective salts ${ }^{3}$. Tyrosine was recrystallized from hot water, and glycine and alanine from water by adding absolute ethanol repeatedly until their specific activities became constant.

Radioactivities of the amino-acids isolated from fibroin are summarized in Table I. Almost all the activity was located in tyrosine.

Isolated tyrosine was analysed by paper chromatography, using phenol containing 0.1 per cent ammonia as a solvent. The strip was sprayed with ninhydrin in the usual way, the position of tyrosine 